\title{
DISCRETE SIMULATION APPLIED TO THE PRODUCTION PROCESS OF ELECTRONIC COMPONENTS
}

\author{
Lucas Santos Da Costa \\ IFSP - Câmpus Suzano \\ E-mail: lucascosta23@live.com \\ Willians Dos Santos Lúcio \\ IFSP - Câmpus Suzano \\ E-mail: willians.Ihp1984@hotmail.com \\ Adriano Maniçoba Da Silva \\ IFSP - Câmpus Suzano \\ E-mail: adriano_m_s@hotmail.com \\ William De Paula Ferreira \\ IFSP - Câmpus Suzano \\ E-mail: eng.william.ferreira@gmail.com \\ Submission: 03/01/2017 \\ Accept: 14/01/2017
}

\section{ABSTRACT}

The objective of this research is to demonstrate through simulation techniques and analyses performed in production systems of a company located in the city of Guarulhos, which produces an electronic component that has plastic, acrylic and steel, the improvements that can be acchieved with the use of a specialist software to assist the manager in decision making. For the study, concepts of simulation, Monte Carlo method, queueing theory and the software Arena were used. By simulating processes and evaluating performance, the software offers reports that assist the manager to see more clearly potential bottlenecks and points of improvement in process, thus effectively contributing to the company's competitiveness on the market. With the study presented in this article it was possible to verify the importance of the use of this tool such as barriers they currently face to grow faster, and to find evidences of how collaboration between organizations could facilitate the process of acquiring competitive advantage. 
DOI: 10.14807/ijmp.v8i5.603

Keywords: Discrete simulation, production process, electronic components.

\section{INTRODUCTION}

Due to the need of organizations to compete with each other, the use of differentiated resources can put their users at an advantage. The simulation through the software Arena becomes a way for the organization to evaluate its operational performance and diagnose possible points through the analysis of reports made available by this program. Time and resource optimization can elevate the organization's service level in order to reduce costs and better serve its customers, thus making the in-depth study of this subject a competitive advantage.

This study consists of demonstrating the efficiency of a simulation software applied to an electronic components production process in a company that initially used flow charts in spreadsheets to work with the tasks performed in this assembly line.

It was verified that this process could be optimized by using the computational tool of simulation, in order to seek a better operational performance through reports that point out possible bottlenecks in the process, helping the responsible manager in the decision-making.

According to Law and Mccomas (1999), the simulation is commonly applied in productive systems. Among the benefits that the simulation provides, these can be highlighted: analysis of machinery and its operators, evaluation of performance and operational procedures.

The software Arena is an important computational tool of simulation due to its ability to simulate a process, in a virtual and assertive way, providing a broad visibility of the capacity of each process's real capacity in a certain period of time and its bottleneck, with the objective of strategically planning, thus avoiding negative unforeseen events, giving an anticipated view of a given situation.

Considering that this study aimed to provide a better method for the distribution of the activities related to the mentioned process and taking into account that in the studies developed in Brazil still not present the discrete simulation of the electronic components production process, we observed this research gap. 
Morabito and Pureza (2010) define simulation as an essential planning tool that tries to imitate, through logical relations, the operation of real systems, so that it is possible to observe its behavior in different scenarios.

\section{BIBLIOGRAPHIC REVIEW}

The literature review will be composed of references to the simulation, its models and basic elements, the Monte Carlo method and the queuing theory and the software Arena, according to renowned authors in the area, thus providing the adequate foundation for the study carried out.

\subsection{Simulation}

According to Pritsker (1986), simulation or computational simulation, as it is also known, is the process of projecting a logical mathematical model of a real system and performing experiments of this system on a computer. Pegden (1990) further complies that simulation is a process that aims to design a computational model of an authentic system and direct experiments with this model in order to understand its behavior and evaluate strategies for its operation.

Simulation is a method used by professionals from a variety of study fields, especially engineering, to provide a practical, lean, focused and in-depth solution to the most complex problems faced daily. The use of the simulation is due to its handling through sophisticated environments and the development of computational models, becoming a tool used by large companies in several countries that seek to minimize costs and maximize profits.

In order to do this, it is important the use simulation software that deals with tools that help the development of virtual operations of the entire production process. There are no consequences in an objective way, generating accurate reports that support the manager for decision-making.

Harrel and Tum (1997) define simulation as an activity through which conclusions can be drawn regarding the behavior of a given system by studying the behavior of the model corresponding to it in which the cause and effect relationships are the same or similar to the real system.

The simulation uses not only the construction of models, but also an experimental method where the system's behavior is verified, it builds theories and 
DOI: 10.14807/ijmp.v8i5.603

hypotheses predicting the future behavior, that is, effects produced through changes in the system or analyzes used according to the need for its operation. Through the simulation, it is possible to identify the identification of lead-time, bottlenecks, size of stocks, use of workers and machines and the production volume, so that it highlights the decision making with greater clarity and efficiency.

According to Lobão and Porto (1996) and Ören and Yilmaz (2012), the simulation has a succession of inferences about the most varied activities in the production systems, for example: problem identification; comparison with the other systems' performance; studies regarding the use of real capacity, inventory indexes, control logic, sequencing, system problems, better layout and better level of operator productivity; employees training; sensitivity analysis; planning and acquisition assistance and prediction of behavior and performance.

\subsection{Basic elements of the simulation}

The simulation constitutes of basic elements that, according to Banks and Carson II (2004), are defined as:

Entities: entities are the parts that "circulate" on the model, affect and are affected by other entities, occupy resources and queues, and interfere with the state of the system. Entities can be identified through batches or units.

Attributes: they are proper characteristics of the entity, but can assume values that differentiate each one. Attributes are entity-only specifications.

Variables: these are information that reflect some characteristics in the system, independently on the entities. They are variations, which occur during the course of the system, according to the need to organize the information.

Resources: They provide services to entities. Resources that can be human or not and that provide some type of service to entities and add value to that activity.

Queues: Locations occupied by entities while waiting for a resource to be unoccupied by another activity or entity. They are generated in the course of the process and generally require a balance in the system so that they can be fluid.

\subsection{Systems and models of simulation}

For Seila (1995), a system is a set of components or entities that interacts with each other. These systems may be discrete or continuous, or a join of both. 
Some softwares have been developed to model discrete or continuous systems or the combination of both.

The systems are said to be discrete as the variables involved assume finite or infinite numerable values (for example, pieces arriving at a machine) and continuous as the variables change continuously in time (for example, kilometers driven by the trucks in the simulation of a logistic system), in this case the languages of simulation must be able to solve systems of differential equations.

In discrete event simulations the programs are equipped with a clock, which is initialized with the event to which it is linked and advances until the next event is programmed (PEREIRA, 2000).

There are two types of simulation models: the deterministic, that according to Reis and Martins (2001, p.58), "it is assumed that the data are obtained with certainty". In these models of simulation there are no random variables, the input data will have a single set of output results.

It is stochastic, according to Nascimento and Zucchi (1997), which includes the probabilistic behavior in the internal relation of the system, with the objective of capturing the probabilistic nature that involves the variables surrounding the system, through the use of statistical technique and the use of computers. In this case, there is one or more random variables as input, which leads to random outputs.

The probabilistic models of simulation come from the Monte Carlo method and focus on random phenomena, including risk analysis, incorporating the environmental variables and, consequently, the elements of uncertainty (NASCIMENTO; ZUCCHI, 1997).

The following table gives a brief summary of the computational simulation concepts: 
Table 1: Summary of simulation concepts

\begin{tabular}{|c|c|c|c|}
\hline SYSTEM & \multicolumn{2}{|l|}{ MODEL } & SIMULATION \\
\hline $\begin{array}{l}\text { DISCRETE: } \\
\text { variables involved } \\
\text { assume } \\
\text { numerable finite } \\
\text { or infinite values. }\end{array}$ & $\begin{array}{l}\text { DETERMINISTIC: } \\
\text { variables assume } \\
\text { certain values. }\end{array}$ & $\begin{array}{l}\text { STATIC: } \\
\text { studies the } \\
\text { system } \\
\text { without } \\
\text { taking into } \\
\text { account its } \\
\text { variability } \\
\text { with time. }\end{array}$ & $\begin{array}{l}\text { TERMINANT: there } \\
\text { is interest in } \\
\text { studying the system } \\
\text { in a given time } \\
\text { interval. }\end{array}$ \\
\hline $\begin{array}{l}\text { CONTINUOUS: } \\
\text { variables change } \\
\text { constantly over } \\
\text { time. }\end{array}$ & $\begin{array}{l}\text { STOCHASTIC: } \\
\text { variables assume } \\
\text { different values } \\
\text { according to a given } \\
\text { probability } \\
\text { distribution. }\end{array}$ & $\begin{array}{l}\text { DYNAMIC: } \\
\text { represents } \\
\text { the system at } \\
\text { any time. }\end{array}$ & $\begin{array}{l}\text { NON TERMINANT: } \\
\text { there is an interest } \\
\text { in studying the } \\
\text { system from a } \\
\text { certain stable state, } \\
\text { and the study can } \\
\text { continue } \\
\text { indefinitely. }\end{array}$ \\
\hline
\end{tabular}

Source: Pereira (2000)

\subsection{Monte Carlo Method and the Queuing Theory}

The term Monte Carlo was given by the researchers S. Ulam and Nicholas Metropolis in tribute to Monte Carlo's, Monaco, most popular activity, the games (GUJARATI, 2002). The Monte Carlo Method is defined according to Hammersley and Handscomb (1964) as the part of experimental mathematics that is focused on experiments with random numbers. This method is based on relative numbers and statistical probability, a technique that involves random values for problem solving.

Monte Carlo is used when the situation predicts the use of random statistical data and look for probabilities, thus finding variations that help in the arrival of conclusions of a certain system. According to Moore and Weatherford (2006), the Monte Carlo method is one of several methods to analyze the propagation of uncertainty, where its greatest advantage is the determination of how a known random variation or error affects the performance or the viability of the system being modeled.

According to Prado (2008), the analytical method that approaches the subject through mathematical forms is called queuing theory. According to Aurélio (2008), a queue is defined as a row of people positioned in front of each other in the chronological order of arrival at a specific boarding point, or a data organization structure in which they are retrieved in the same order as they were entered.

These queues arise according to the demand and capacity of an operation, the larger the demand, the larger the queue if the capacity is not adequate to this 
demand, because of this, these are the big factors causing bottlenecks in queues, resulting in delays in the process and quality loss of the product or service.

Filho (2008) states that over time and in the face of realities, methods of queuing analysis have emerged, such as the use of computer systems and software and that simulation through the insertion of collected data, to reach improvements and solutions of the problem with its delimitations and the methodological proposal.

It can be said that the queue is formed with the arrival of the client to the system, taking into account the waiting time in the queue, the time of attendance and the time that the entity passes through the system. Any processes in which people arrive to receive a service by which they wait, may be called a queue (FOGLIATTI; MATTOS, 2007).

The queue discipline for Taha (2008) is a series of rules which determine the order of customer service, and that this service can be performed considering the coming order, being the first to come the first to be serviced (FIFO - First In First Out), the last to come the first to be serviced (LIFO - Last In First Out), random, that is, the calls are made without considering the arrival order and, with priority, the calls are made according to established priorities.

\section{METHODOLOGY}

In the beginning, the case study had the idea of providing to researchers (students) real experiences in the field so that they could develop experience for facing the real world, assuming responsibilities, critical vision and self-independence, thus no longer needing their teachers and mentors.

Yin (2001) conceptualizes case study as an empirical investigation that investigates a contemporary phenomenon within its real-life context, especially when the boundaries between phenomenon and context are not clearly defined.

According to Yin (2001), it is interesting to carry out a pilot case study before collecting data from the final cases of the research. This can be chosen for several reasons that have nothing to do with the criteria used to select the final cases in the case study project. Among these reasons, it is possible to mention the ease of access to informants, geographic convenience of the site, the existence of a large amount of data and documents to be collected, or even the location represents the most complicated of real cases. 
The pilot case study assists researchers in improving the plans for data collection, both in terms of data content and the procedures to be followed. It is used in a formative way, helping the researcher to develop the relevant alignment of the issues. In general, convenience, access to data and geographical proximity may be the main criteria for selecting the case or pilot cases (YIN, 2001).

\section{RESULTS}

\subsection{Current situation descriptions}

This case study was carried out in a large company located in the city of Guarulhos, which performs in one of its processes the machining of three different types of raw material, namely plastic, acrylic and steel, used for the manufacture of an electronic component.

In order to machine these raw materials, three different processes are used for each type of material, in which the "Tulip" process is for plastic machining, the "Bell" process is for acrylic machining and the "Axis" process is for the steel machining, each production process receives at the beginning of its line one piece of raw material every 57 seconds in a constant way, in which each process has to machine about 500 pieces in an 8 hour shift. Since the "Tulip" process and the "Bell" process work one shift while the "Axis" process works two shifts.

In each process a machine is used to perform the piece machining, in which all the machines need to adjust their parameters to each step, this will only happen for the first piece that is machined in that step, the others follow normally. The machines have different numbers of steps, as needed for each raw material.

After the pieces go through the machining process, they proceed to the assembly of the components containing a plastic piece, an acrylic piece and a piece of steel, thus forming a single component, this assembly is performed by a production assistant that spends around 3 minutes to complete this assembly. After assembly a forklift operator, who spends around 7 minutes to perform this activity, took this component to the company stock.

Below, the current situation of the company and the activities described above are represented in the form of a flowchart, as shown in Figure 1. 
DOI: 10.14807/ijmp.v8i5.603

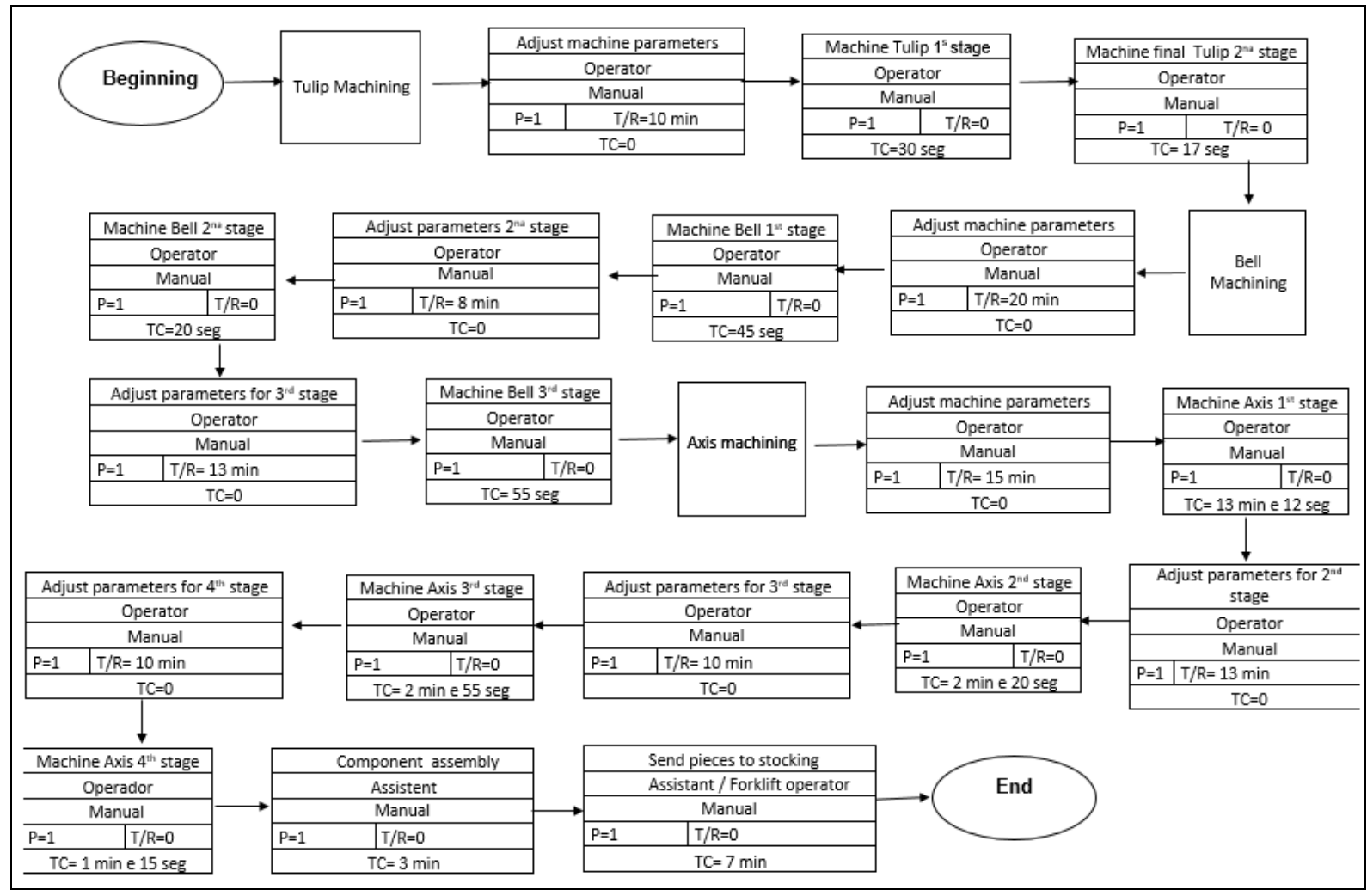

Figure 1: Simulation flowchart

Source: Created by the authors

This flowchart is currently used as the basis for all planning of this process within the company.

\subsection{Modeling in the Software Arena}

According to the current situation of the company presented above, it was verified that there was scope for improvement within this activity. From this flowchart, a simulation of this process was mounted in the software Arena. The study aimed to improve the performance of machines and operators that are part of this operation.

Verifying the need for improvement in the process, the following bottlenecks in the current system were diagnosed:

- Case 1 - Great time demand: in the "Axis" process for steel machining at an average time of 2 minutes and 43 seconds, while the "Tulip" process for machining plastic took an average time of 23 seconds, and in the "Bell" process for acrylic machining, an average time of 40 seconds. Therefore, it has been verified that there is a very great time demand for steel machining to take place, subsequently causing a production queue. In addition, this is causing an extra turn for this process and the next ones. 
- Case 2 - Assembly of the component: during the component assembly process, the production assistant spends 3 minutes to execute the task, again causing a high demand of time and queue.

- Case 3 - Sending the components to the stock: when sending the components to the stock, the forklift operator takes 7 minutes to leave the production area and take the component to the inventory, causing a new waste of time and blocking the process through the formation of large queues.

In this above analysis, it was observed that in addition to the loss of time, there is a big problem with queues that form and cause the company to have two shifts for the "Axis" process, component assembly and dispatch to the component stock.

After the observation of these bottlenecks, the necessary improvements were identified so that there is a production with greater balance, which are:

- Case 1 - The improvement identified and possible for this case is the company to provide specific trainings for the "Axis" process machine operators that would improve their performance in up to 1 minute and 53 seconds, reaching the task in 50 seconds only. Therefore, it was simulated generating a flow of the line in a balanced way with the "Tulip" and "Bell" processes.

- Case 2 - For this case, it was considered the use of a robot to assemble the components, taking 10 seconds to fulfill it, which would reduce the time loss in 2 minutes and 50 seconds and labor costs.

- Case 3 - In this case, it was identified that the company has a structure for the installation of a treadmill that would make this transition between production and stock in 15 seconds, reducing in 6 minutes and 45 seconds in time, and a forklift and an operator in costs. According to the improvements found, a simulation of the system in the software Arena was performed based on the times that were questioned during the study, in order to simulate if the improvements could actually occur and what would be the results obtained through the analysis of the reports made available by the software itself. 
ISSN: 2236-269X

DOI: 10.14807/ijmp.v8i5.603

\subsection{Analysis of the results}

The tables and graphs below demonstrate the reports provided by the software Arena, where present the relevant entities, queues and resources (Entity, Queue and Resource) managed in this process:

Table 1: Report of entities regarding the input and output of pieces (Entity, Number In / Number Out):

\begin{tabular}{|l|l|l|l|}
\hline \multicolumn{4}{|c|}{ Entity } \\
\hline \multicolumn{4}{|c|}{ Number of inputs } \\
\hline & Average & $\begin{array}{l}\text { Minimum } \\
\text { average }\end{array}$ & $\begin{array}{l}\text { Maximum } \\
\text { average }\end{array}$ \\
\hline Steel piece & 500 & 500 & 500 \\
\hline Acrylic piece & 500 & 500 & 500 \\
\hline Plastic piece & 500 & 500 & 500 \\
\hline \multicolumn{2}{|c|}{ Source: Created by the authors of the study }
\end{tabular}

This table shows the amount of pieces that made part of the process.

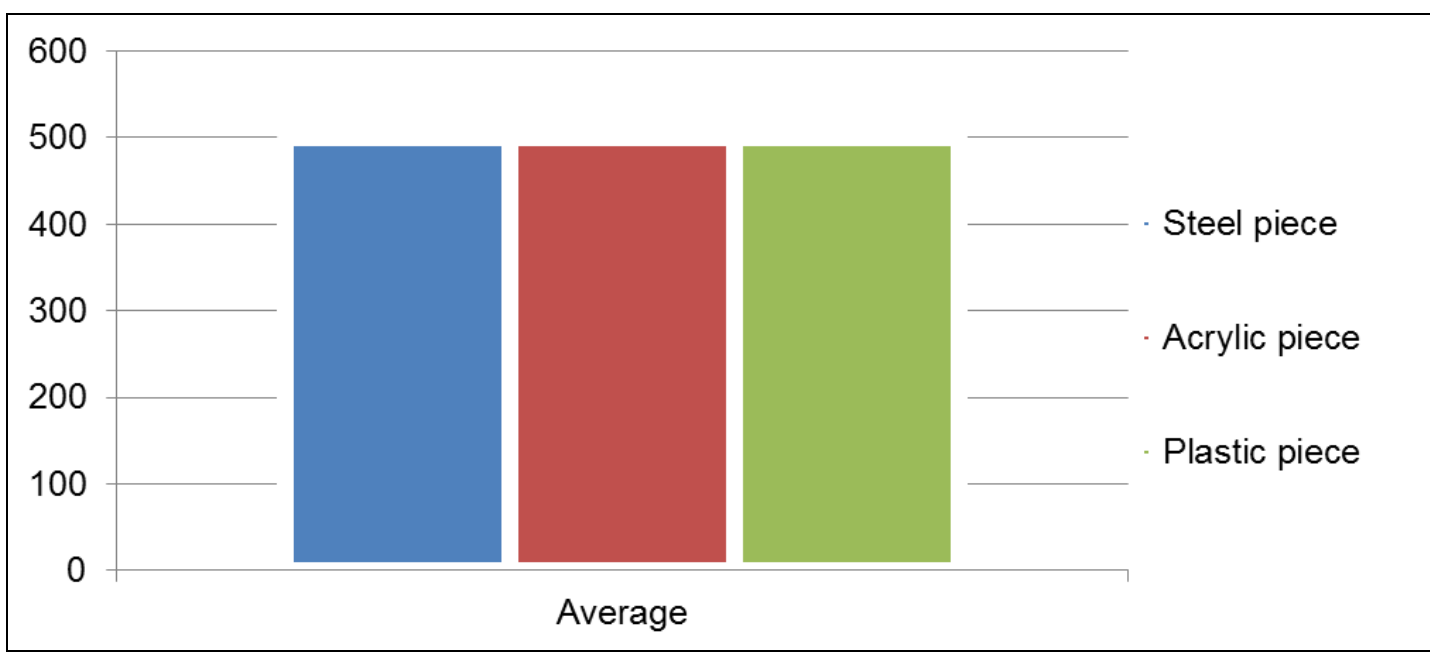

Graphic 1: Inputs

Source: Created by the authors of the study

Table 2: Number of Outputs

Number of outputs (Number Out)

\begin{tabular}{|l|l|l|l|}
\hline & Average & $\begin{array}{l}\text { Minimum } \\
\text { average }\end{array}$ & $\begin{array}{l}\text { Maximum } \\
\text { average }\end{array}$ \\
\hline Steel piece & 498 & 498 & 498 \\
\hline Acrylic piece & 498 & 498 & 498 \\
\hline Plastic piece & 498 & 498 & 498 \\
\hline
\end{tabular}

Source: Created by the authors of the study

This table refers to the amount of pieces that composes the process output. 
DOI: 10.14807/ijmp.v8i5.603

Table 3: Work in Process

\begin{tabular}{|l|l|l|l|l|l|}
\hline WIP & Average & $\begin{array}{l}\text { Minimum } \\
\text { average }\end{array}$ & $\begin{array}{l}\text { Maximum } \\
\text { average }\end{array}$ & $\begin{array}{l}\text { Minimum } \\
\text { Value }\end{array}$ & $\begin{array}{l}\text { Maximum } \\
\text { Value }\end{array}$ \\
\hline Steel piece & 5.947 & 5.947 & 5.947 & 0 & 12 \\
\hline Acrylic piece & 5.428 & 5.428 & 5.428 & 0 & 11 \\
\hline Plastic piece & 4.909 & 4.909 & 4.909 & 0 & 10 \\
\hline \multicolumn{7}{|c|}{ Source: Created by the authors of the study } \\
\hline
\end{tabular}

This table shows the pieces that remained under process after the period studied.

Graphic 1 shows the number of raw material pieces that entered the process and the Number Out field shows the quantity of raw material that came out of the process, being that, in an 8 hour shift, the maximum capacity of each process is 500 pieces, so it was observed that 2 pieces in each process was kept in production at the end of the shift. In the WIP (Work In Process) field, it Is possible to see the average number of pieces that were in process during the shift and the maximum number of pieces that were in process.

Table 4: Report of queues in relation to the waiting time (Queue / Waiting Time):

\begin{tabular}{|c|c|c|c|}
\hline \multicolumn{4}{|l|}{ Queue } \\
\hline \multicolumn{4}{|l|}{ Waiting time } \\
\hline & Average & $\begin{array}{l}\text { Minimum } \\
\text { average }\end{array}$ & \begin{tabular}{|l|}
$\begin{array}{l}\text { Maximum } \\
\text { average }\end{array}$ \\
\end{tabular} \\
\hline 1 Stage Bell & 0.00005833 & 0.00 & 0.01166667 \\
\hline 1 Stage Axis & 0.00018333 & 0.00 & 0.01194444 \\
\hline 1 Stage Tulip & 0.00000167 & 0.00 & 0.00083333 \\
\hline 2 Stage Bell & 0.00 & 0.00 & 0.00 \\
\hline 2 Stage Axis & 0.00031778 & 0.00 & 0.01388889 \\
\hline 2 Stage Tulip & 0.00 & 0.00 & 0.00 \\
\hline 3 Stage Bell & 0.00325389 & 0.00 & 0.03694444 \\
\hline 3 Stage Axis & 0.00053056 & 0.00 & 0.00 \\
\hline 3 Stage Tulip & 0.00 & 0.00 & 0.00 \\
\hline 4 Stage Axis & 0.00096944 & 0.00 & 0.01388889 \\
\hline Pieces to stock & 0.001388889 & 0.00 & 0.00277778 \\
\hline Assembling & 0.00277778 & 0.00 & 0.00555556 \\
\hline Set 1 assembling & 0.04650722 & 0.04250000 & 0.1150 \\
\hline Set 2 assembling & 0.02211889 & 0.00 & 0.05500000 \\
\hline Set 3 assembling & 0.00000611 & 0.00 & 0.01388889 \\
\hline
\end{tabular}


INDEPENDENT JOURNAL OF MANAGEMENT \& PRODUCTION (IJM\&P)

http://www.ijmp.jor.br

v. 8, n. 5, Special Edition IFLOG 2016

ISSN: 2236-269X

DOI: 10.14807/ijmp.v8i5.603

This table contains data referring to the waiting time of the entities on queue.

Table 5: Report of queues in relation to the amount of entities waiting (Queue /

Number Waiting):

\begin{tabular}{|c|c|c|c|}
\hline \multicolumn{4}{|l|}{ Queue } \\
\hline \multicolumn{4}{|l|}{ Waiting time } \\
\hline & Average & $\begin{array}{l}\text { Minimum } \\
\text { average }\end{array}$ & $\begin{array}{l}\text { Maximum } \\
\text { average }\end{array}$ \\
\hline 1 Stage Bell & 0.00364583 & 0 & 1 \\
\hline 1 Stage Axis & 0.01145833 & 0 & 1 \\
\hline 1 Stage Tulip & 0.00010417 & 0 & 1 \\
\hline 2 Stage Bell & 0 & 0 & 0 \\
\hline 2 Stage Axis & 0.01986111 & 0 & 1 \\
\hline 2 Stage Tulip & 0 & 0 & 0 \\
\hline 3 Stage Bell & 0.2034 & 0 & 3 \\
\hline 3 Stage Axis & 0.03315972 & 0 & 1 \\
\hline 3 Stage Tulip & 0 & 0 & 0 \\
\hline 4 Stage Axis & 0.06059028 & 0 & 1 \\
\hline Pieces to stock & 0.2604 & 0 & 1 \\
\hline Assembling & 0.5208 & 0 & 2 \\
\hline Set 1 assembling & 29.067 & 0 & 8 \\
\hline Set 2 assembling & 13.824 & 0 & 4 \\
\hline Set 3 assembling & 0.00038194 & 0 & 1 \\
\hline
\end{tabular}

Source: Created by the authors of the study

Table 4 shows the average waiting time (in minutes) in the queue and Table 5 the average number of pieces waiting to be machined and assembled respectively.

Table 6: Report of resources:

\begin{tabular}{|l|l|l|l|}
\hline \multicolumn{2}{|l}{ Resources } & \multicolumn{2}{l|}{} \\
\hline \multicolumn{2}{|l}{ Occupation number } \\
\multicolumn{2}{|l}{} & \multicolumn{2}{l|}{} \\
\hline & Average (\%) & $\begin{array}{l}\text { Minimum } \\
\text { average }\end{array}$ & $\begin{array}{l}\text { Maximum } \\
\text { average }\end{array}$ \\
\hline Treadmill & 0,7813 & 0 & 1 \\
\hline Bell 1 Operator & 0,04166667 & 0 & 1 \\
\hline Bell 1.1 Operator & 0,7813 & 0 & 1 \\
\hline Bell 2 Operator & 0,01666667 & 0 & 1 \\
\hline Bell 2.2 Operator & 0,3472 & 0 & 1 \\
\hline Bell 3 Operator & 0,02708333 & 0 & 1 \\
\hline Bell 3.3 Operator & 0,9549 & 0 & 1 \\
\hline Axis 1 Operator & 0,0625 & 0 & 1 \\
\hline Axis 1.1 Operator & 0,8681 & 0 & 1 \\
\hline Axis 2 Operator & 0,02708333 & 0 & 1 \\
\hline
\end{tabular}


ISSN: 2236-269X

DOI: 10.14807/ijmp.v8i5.603

\begin{tabular}{|l|l|l|l|} 
Axis 2.2 Operator & 0,8681 & 0 & 1 \\
\hline Axis 3 Operator & 0,02083333 & 0 & 1 \\
\hline Axis 3.3 Operator & 0,8681 & 0 & 1 \\
\hline Axis 4 Operator & 0,02083333 & 0 & 1 \\
\hline Axis 4.4 Operator & 0,8681 & 0 & 1 \\
\hline Tulip 1 Operator & 0,02083333 & 0 & 1 \\
\hline Tulip 1.1 Operator & 0,5208 & 0 & 1 \\
\hline Tulip 2 Operator & 0,01458333 & 0 & 1 \\
\hline Tulip 2.2 Operator & 0,2951 & 0 & 1 \\
\hline Robot & 0,5208 & 0 & 1 \\
\hline
\end{tabular}

Table 6 shows the average utilization level of each resource used in this activity in percentage (\%) and its respective graphic (Graphic 2) below. In the "Bell" process, there are 3 operators, where "Bell 1 Operator" makes the adjustment in the first weight and then follows as "Bell Operator 1.1" for its respective line, and so on for all other operators (this rule is stipulated for all operators).

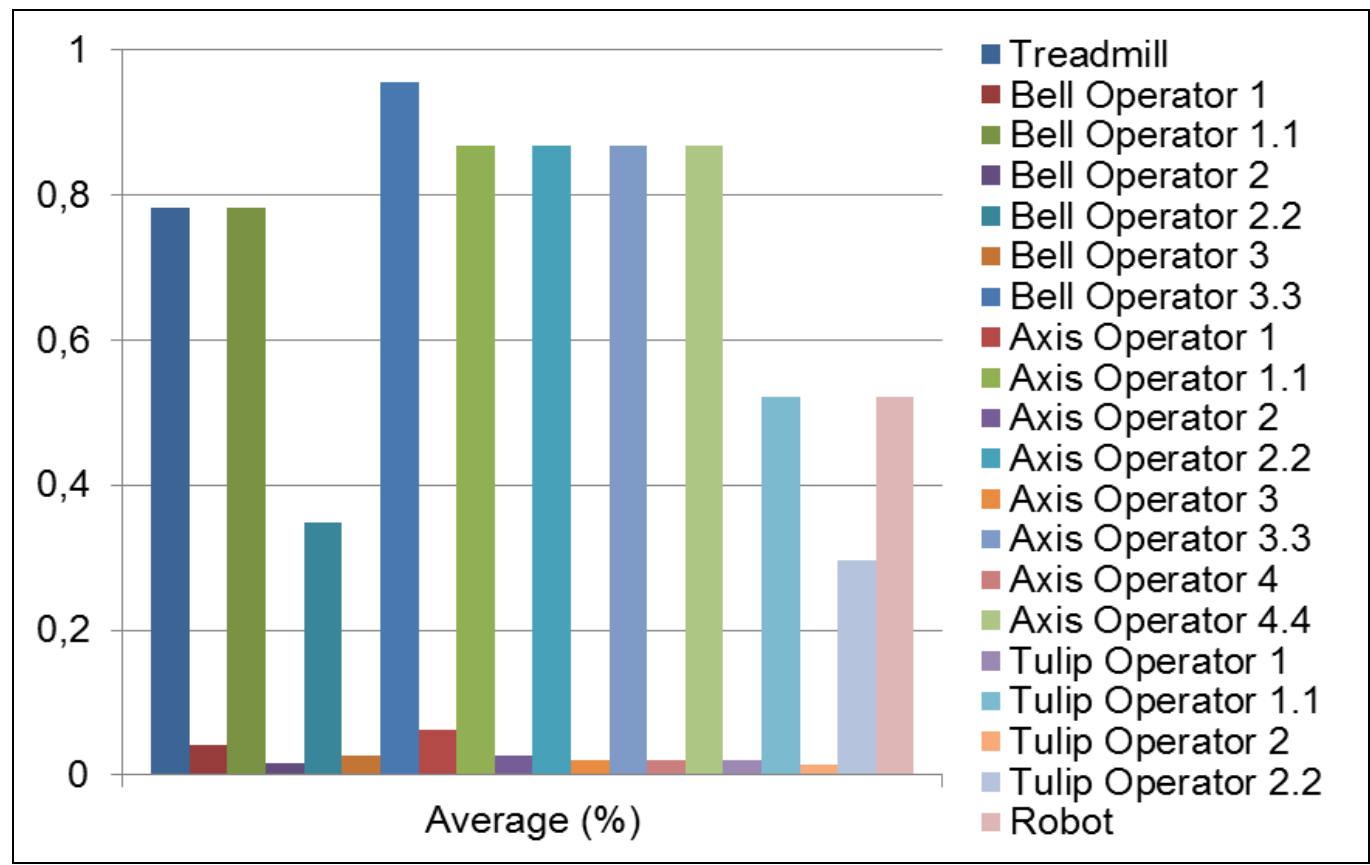

Graphic 2: Use of resources

Source: Created by the authors of the study

In the graph it was observed that the "Robot" used for the assembly has about $50 \%$ of its time occupied, a satisfactory number since previously it was used an auxiliary that was supercharged in this function. The same thing happens with the "Treadmill" resource, which used about $80 \%$ of its time. 
Table 7: Report of resources:

\begin{tabular}{|l|l|}
\hline \multicolumn{2}{|l|}{ Resources } \\
\end{tabular}

According to Table 7, it is possible to verify the count made on the number of pieces that have passed through all the resources.

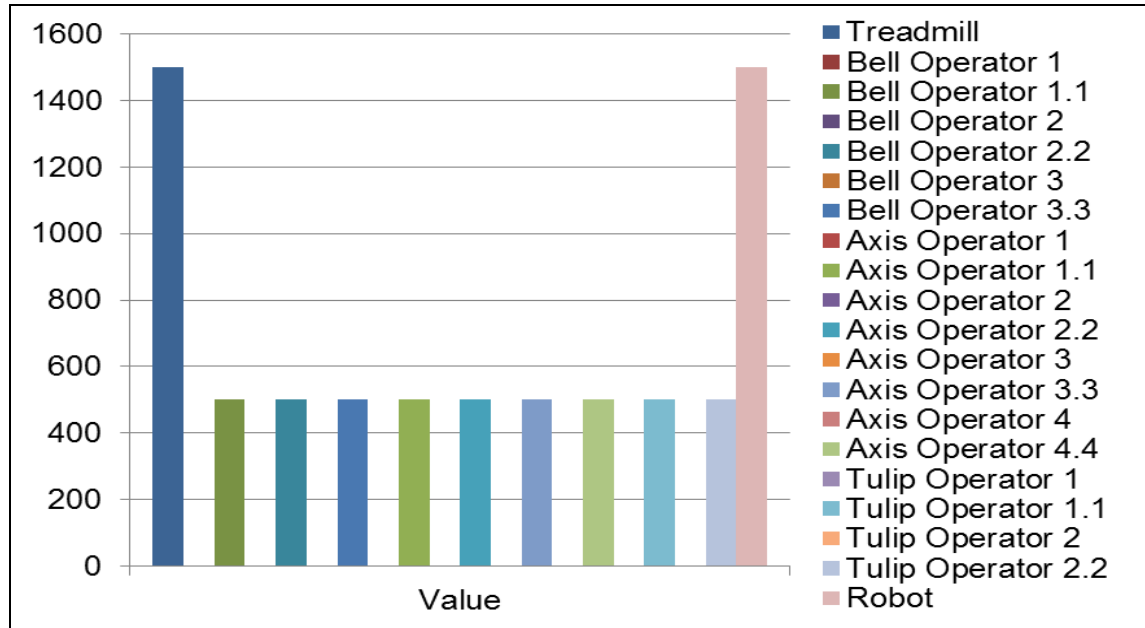

Graphic 3: Quantity

Source: Created by the authors of the study 
The graphic shows data presented in the previous table.

\section{DISCUSSION OF THE RESULTS}

According to the results presented in the research it was possible to verify, the improvement of the process through the data made available in the tables and graphics related in the previous topic. Because of this, the use of resources of technology like the software Arena can be taken into account now of a strategic decision is made with the simulation being used as a parameter to analyze and help the management.

The obtained bibliographical references based the analysis conducted in this process, in which through other studies related to the simulation functions applied in this case became adequate and timely for the optimization of a productive flow carried out in electronic spreadsheets for a simulation system proposed in the software Arena that reduces costs.

The concepts used in the dialogue with the research results demonstrate the efficiency of the simulation knowledge in relation to the method that was previously used by the company; the improvements indicated by the software prove this and give opportunity for cost reduction in production, handling and stocking, since it was seen a one-shift reduction in the company.

\section{FINAL CONSIDERATIONS}

According to the studied situation, the application of simulation methods becomes feasible to companies, since it brings a panoramic view of the process in which initially there was only the use of flowcharts, which are limited. The software Arena clearly and objectively demonstrates relevant information about outbound, inbound, work in process and idleness, giving the manager greater control and power in decision-making.

In this study it was verified that in the company in which the simulation was applied there was a great improvement in the process from the use of the software Arena, there was a gain in several sectors in time and the reduction of one shift in the "Axis" process, thus balancing all the company's production line. The reports presented during the research prove that the simulators bring benefits so that the strategic planning of the company can be more and more competitive, minimizing 
costs and maximizing profits. The objective of the study was satisfactorily achieved from the perspective of the research that sought to apply the simulation and software methods in the existing process in the company and demonstrate improvements in the production of electronic components, in addition to optimize time, resources and materials, as well as minimizing costs of the process studied.

We can assume, then, that the applications of these methods are recommended for other productive processes within the company and because of the high competitiveness in the market several organizations can adapt to this new reality, since the simulation covers diverse study fields and is gaining more and more power in the market.

\section{REFERENCES}

AURÉLIO, FERREIRA. B. H. (2008) Novo Dicionário Aurélio. Ed. 4. Curitiba: Positivo.

BANKS, J.; CARSON II, J. S.; NELSON, B. L.; NICOL, D. M. (2004) Discrete-Event System Simulation. Paperback: Prentice Hall.

FILHO, J. F. (2008) Introdução à Modelagem e Simulação de Sistemas com Aplicações Arena. Santa Catarina: Visual Books.

FOGLIATTI, M. C.; MATTOS, N. M. C. (2007) Teoria de Filas. Editora Interciência. Rio de Janeiro.

GUJARATI, D. N. (2002) Econometria básica. 3a edição. São Paulo: Makron Books.

HAMMERSLEY, J. M.; HANDSCOMB, D. C. (1964) Monte Carlo methods. London: Methuen.

HARREL, C.; TUMAY, K. (1997) Simulation made easy, IIE Solutions, pp.39-41.

LAW, M. A.; MACCOMAS, M. G. (1999) Simulation of manufacturing systems, Proceedings of the 1999 Winter Simulation Conference. p. 56-59.

LOBÃO, E. C.; PORTO, A. J. V. (1996) Proposta de sistematização de estudos de simulação. Revista de Engenharia e Arquitetura - EESC/USP, São Carlos, SP, p. 61-69.

MOORE, J.; WEATHERFORD, L. R. (2006) Tomada de decisão em administração com planilhas eletrônicas. $6^{\mathrm{a}}$ edição. Porto Alegre: Bookman Companhia Editora.

MORABITO, R.; PUREZA, V. (2010) Modelagem e simulação. In: CAUCHICK MIGUEL, P.A.C. et al. Metodologia de pesquisa em engenharia de produção e gestão de operações. Rio de Janeiro: Elsevier.

NASCIMENTO, A. M.; ZUCCHI, A. L. (1997) Modelos de simulação. São Paulo, Universidade de São Paulo, 1997. 40 p. Monografia - Faculdade de Economia, Administração e Contabilidade, Universidade de São Paulo, São Paulo. 
ÖREN, T.; YILMAZ, L. (2012) Synergies of simulation, agents, and systems engineering. Expert Systems with Applications, v. 39, p. 81-88.

PEREIRA, I. C. (2000) Proposta de sistematização da simulação para fabricação em lotes. Dissertação (Mestrado em Engenharia de Produção) do Programa de Pós-Graduação em Engenharia de Produção, UNIFEI, Itajubá/MG.

PRADO, D. S. (2008) Usando o Arena em Simulação. 3. Ed. Belo Horizonte: Indg, 305 p. (Pesquisa Operacional volume 3).

PEGDEN, C. D. et al. (1990) Introduction to simulation using SIMAN. NY: McGraw-Hill, 2nd ed.

PRITSKER, A. A. B. (1986) Introduction to simulation and slam II. New York: John Wiley \& Sons.

REIS, S. G.; MARTINS, E. (2001) Planejamento do balanço bancário: desenvolvimento de um modelo matemático de otimização do retorno econômico ajustado ao risco. Revista Contabilidade \& Finanças, São Paulo, v. 15, n. 26, p. 58-80, Maio/Agosto.

SEILA, A. F. (1995) Introduction to simulation. Proceedings of the 1995 Winter Simulation Conference.

TAHA, H. A. (2008) Sistemas de Filas. In: TAHA, H. A. Pesquisa Operacional. Ed. 8. São Paulo: Person Prentice Hall. Cap. 15, p. 247-270.

YIN, R. (2001) Estudo de caso. Planejamento e métodos. $2^{\mathrm{a}}$ edição, Porto Alegre/RS: Bookman. 